\title{
GROUNDWATER QUALITY ASSESSMENT OF AL-DAKHLA CITY, THE NEW VALLEY, EGYPT
}

\author{
AHMED, A. SHARKAWY ${ }^{1}$; DALIA, M. A. HASSAN ${ }^{2}$ and SAMIRA, A.A. SANOUSY ${ }^{3}$ \\ ${ }^{1}$ Forensic Medicine and Toxicology Dept., Fac. Vet. Med., Assiut University, Assiut, Egypt. \\ ${ }^{2}$ Dept. of Animal Hygiene, Fac. Vet. Med., Assiut University, Assiut, Egypt. \\ ${ }^{3}$ Lab. Institute of Animal Health, The New Valley.
}

Received: 31 March 2019; $\quad$ Accepted: 23 April 2019

\begin{abstract}
This study aimed to clarify the hygienic quality of groundwater samples collected from multiple wells from AlDakhla city, The New Valley, with special reference to heavy metals pollution. Groundwater samples from 10wells were investigated ( 3 samples each). Metals concentrations were determined using the ICP [Inductively Coupled Plasma Emission Spectrometer (ICAP 6200)]. The results revealed that the levels (ppm) of estimated metals were $0.803 \pm 0.011(0.250-3.033)$ for $\mathrm{Pb} ; 0.0082 \pm 0.0008(0.0001-0.0325)$ for $\mathrm{Cd} ; 30.595 \pm 0.197$ (4.225$56.325)$ for $\mathrm{Mn} ; 326.233 \pm 3.077(27.75-512.75)$ for $\mathrm{Fe}$; $0.375 \pm 0.002(0.150-1.125)$ for $\mathrm{Cu}$ and $9.256 \pm 0.222$

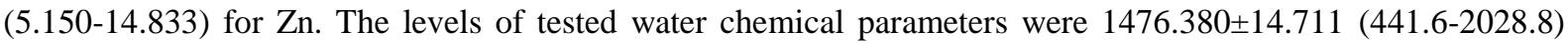
$\mathrm{mg} / \mathrm{l}$ for TDS; $2.307 \pm 0.061(0.690-3.170) \mathrm{dc} / \mathrm{m}$ for EC; $6.186 \pm 0.082$ (5.4 - 6.7) for $\mathrm{pH}$ and $467.5 \pm 13.352$ (275525) for TH.It is found that lead, iron, manganese and zinc mean values are exceeding the MCL (maximum contaminant level) in $100 \%$ of the examined wells. However, copper recorded mean values within the permissible limits listed by each of Egyptian Standards (2007), EPA (2009), WHO (2011) and EU (2014). Eighty percent of examined wells showed total dissolved solids higher than the limits of Egyptian Standards (2007), EPA (2009), WHO (2011). Eighty percent of examined wells recorded EC in higher levelsthan Egyptian standers (2007). Total hardness exceeded the permissiblelevelsin $100 \%$ of the examined wells while $\mathrm{pH}$ values were all in the acidic range which was slightly around the permissible limits.
\end{abstract}

Key words: Groundwater - heavy metals - water quality - electric conductivity - total dissolved solids - pHtotal hardness -Dahkla Oasis - The New Valley.

\section{INTRODUCTION}

Groundwater is a major source of rural and urban population's water supply, as it sustains many wetland ecosystems (Baptiste and Altaff, 2002). Ground water is predominantly preferred for domestic purpose as it is naturally of superior quality and requires little treatment before use. Commonly, ground water is deliberated as less polluted as compared to the surface water as it is less exposed to the external environment (Sampat, 2001).

In Egypt, groundwater is considered as one of the most vital water provisions, ground water is reflected as a secondary source to irrigate the agricultural areas in desert regions and as an essential source for some agricultural lands to which the Nile water is not accessible. In numerous parts of Egypt, ground water is extensively used for many

Corresponding author: Dr. Ahmed, A. Sharkawy E-mail address: ahmedsharkawy61@yahoo.com

Present address: Forensic Medicine and Toxicology Dept., Fac. Vet. Med., Assiut University, Assiut, Egypt domestic purposes in addition to both animal and human drinking (Fahim et al., 1995 and Mamdouh et al., 2003).

Lately, increasing emphasis is being given to studies on groundwater contamination. As groundwater is in a direct contact with both plants and soil, this might be a direct source of groundwater contamination (UNESCO, 2011). Rapid industrialization and urbanization have resulted in elevated emission of toxic heavy metals that entering the biosphere (Gazso, 2001, Nweke and Sanders Lii, 2009). Inappropriate waste management in addition to lack of sanitation are having another potential to spoil the purity of the ground water leading to increase its contamination levels (Daniela and Scagliarini, 2005). Determination of water quality is one of the most important aspects in groundwater studies (Prasad and Rami Reddy, 2011). In spite of its importance, water may become a hazard and a threat to the continuation of life if it gets polluted with harmful or toxic substances (Abbasi and Vinithan, 1999). 
Regarding the evidence of heavy metals toxicity to both animal and human health and biological systems, water pollution by heavy metals came to be a question of substantial public and scientific concern (Anazawa et al., 2004). The toxic effects of heavy metals that even in relatively low doses fall under very dangerous environmental pollutants (Kastori et al., 1997).

Lead is not a crucial trace element in any of living organisms and has not any biological function. It can cause a multiplicity of harmful health effects and is known as a fatal neurotoxin (Thomson and Parry, 2006). Mining processes and leaded gasoline are the fundamental sources that introducing lead to the aquatic environment (Prosi, 1989). Leaded gasoline release organometallic lead compounds, while mining processes release inorganic lead forms. Both organic and inorganic lead poses serious health risks to all forms of life (Ewers and Schlipköter, 1990). Inorganic lead compounds (sulfide, carbonate, and sulfate minerals) have low solubility in natural water. In ordinary environmental conditions, lead that is naturally-occurring in mineral deposits is not very mobile, but becomes slightly more soluble under moderately acidic surroundings (Gambrell et al., 1991).

Cadmium (Cd) is considered as a member of the highest dangerous contaminant in the current age, (Wang et al., 2009). It is never be required by organisms even in minute amounts (Laws, 1981). Cadmium main sources are food and water, via the addition of cadmium to agricultural soil and rivers from effluents or fertilizers application (WHO, 1985). Even in low concentrations, $\mathrm{Cd}$ is particularly toxic, undergoes bio-accumulation in both organism body and ecosystem where it has along biological half-life. Long term exposures to $\mathrm{Cd}$ induce renal hurt where kidneys become its critical target organ (EPA 2009). Cadmium is deliberated as one of the priority contaminants form monitoring in most nations and international organizations (EhiEromosele and Okiei, 2012; Mohod and Dhote, 2013).

Manganese (Mn) is a vital trace element involved in some physiological functions but in excessive high doses it converts to harmful element. Manganese is normally found in rocks and soil and exists in well water as a ground water mineral or in high concentration due to underground pollution. The most common exposure sources in both animal and human are an oral exposure through dietary intake of some feeds containing $\mathrm{Mn}$ as well as drinking water and polluted air (WHO, 2006).

Iron $(\mathrm{Fe})$ is one of the most abundant metals in the earth's crust, this makes drinking water has substantial iron concentrations. In water, iron is either in ferrous or ferric state. Ferric hydroxide is the form of iron that is mostly found in ground water (Ghulman et al., 2008 and Oyeku and Eludoyin, 2010). Below certain values, iron is usually regarded to be non-toxic (EPA, 2005). Prolonged ingesting of drinking water with high concentration of iron may lead to liver illness called as haermosiderosis (Rajappa et al., 2010 and Bhaskar et al., 2010).

Copper $(\mathrm{Cu})$ is a common metal that occurs in nature, it is found in relatively low concentrations in natural waters (U.S. EPA, 1976). It is a necessary trace element that required to the body in trace limit. In excessive amounts, copper can be toxic to an animal and human body as it resulting in many diseases including: hepatic cirrhosis, hemolytic anemia and degeneration of basal ganglia (Hefnawy and El-khaiat, 2015). Prolonged exposure of animal to high levels of copper in contaminated drinking water definitely results in liver and kidney damage (Madsen et al., 1990 and Bent and Bohm, 1995).

Zinc is one of metals found in low concentration in surface water due to itsrestrictedmobility from the site of rock weathering as a natural source. Zinc is an element that involved in numerous physiological and metabolic processes in an animal body. It plays a role in protein synthesis; nevertheless, higher zinc values could be toxic to all organisms (Rajappa et al., 2010 and Rajkovic et al., 2008).

Physical and chemical water parameters vastly affected the availability and toxicity of heavy metals (Zhou et al., 2008), especially $\mathrm{pH}$, hardness, total dissolved solids and electrical conductivity (Florence et al., 1992; Adhikari et al., 2006 and Shuhaimi-Othman et al., 2009). Water is regarded as polluted water as it recorded high values of total dissolved solids, hardness and electrical conductivity (Ravindark et al., 2003).

Total dissolved solids (TDS) is an imperative parameter for drinking water, where water with high TDS content is of inferior palatability and can produce unfavorable physiological reaction in the transient consumer (Abdul Jameel, 2002 and Basavaraddi et al., 2012). Total dissolved solidscause increasing in salinity levels, changes in the ionic composition of water (Phyllis et al., 2007). Water hardness plays a role in metals solubility, speciation (Adhikari et al., 2006) and concentration of free metal ions and regulates metal toxicity (FurhanIqbal, 2005).

Electrical conductivity (EC) is a measure of water's ability to conduct an electric current. This ability mainly depends on many factors including: water 
content of anions and cations, the mobility of ions and temperature. It is correlated to the water content of dissolved solids, but it does not give an indication of which element is present. Increasing value of EC is a respectable indicator of the presence of certain contaminants such as chloride, sodium and potassium (Orebiyi et al., 2010).

Egypt is facing a growing water demand by the promptly growing population, increased urbanization, higher standards of both living and agricultural policy. The Western Desert of Egypt is considered as important area for future expansion depending on the groundwater resources. Groundwater requires additional studies concerning its quantity, quality and sustainability for both drinking and irrigation purposes. Heavy metals are among the major pollutants of water sources and their presence is widespread.

The aim of the conducted study is (1) estimation of some heavy metals including: lead, cadmium, manganese, copper, iron and zinc in the groundwater samples. (2) Determination of some chemical characteristics including $\mathrm{pH}$, water hardness, EC and TDS in groundwater samples collected from wells located in Al-Dakhla Oasis (The New Valley, Egypt).

\section{MATERIALS AND METHODS}

[1] Area of study: This study was conducted in AlDakhla district, at February, 2018. Al-Dakhla district lies in the New Valley governorate which is situated $350 \mathrm{~km}$ far from the Nile River, on the south western part of Egypt western desert, sharing the international borders with both Sudan (to the south) and Libya (to the west) (Figure 1). Al-Dakhla district is located about $190 \mathrm{~km}$ west of Al-Kharga district (which is $230 \mathrm{~km}$ South- West of Assiut Governorate).

[2] Samples collection: Groundwater samples (30) from ten wells (10) are located at different localities at Al-Dakhla district were collected for examination of their water quality. From each well three replicate samples were collected for analysis with two intervals. All glass bottles were cleaned and thoroughly rinsed with water to be analyzed before water sampling. All reagents used were of analytical grade. Immediately after sampling, $\mathrm{pH}$ values were estimated in site then, few drops of $\mathrm{HNO}_{3}$ (ultrapure grade) were added to prevent loss of metals, bacterial and fungal growth. Samples were stored in a refrigerator at $1-4^{\circ} \mathrm{C}$ prior to analysis in the laboratory. During sampling all precautions were taken as in the standard guidelines, to avoid any possible contamination.

\section{[3] Water analysis:}

\section{(A) Heavy Metal Analysis:}

1- Sample digestion: One hundred $\mathrm{ml}$ of each groundwater sample was filtered using ashless what man filter paper (to ensure the removal of organic impurities from samples and thus preventing interference with the analysis) and digested with 5 ml of concentrated $\mathrm{HNO}_{3}$ until complete digestion was obtained. For determination of different metals, standards of known concentrations were prepared for each element, followed by calibration of the wave length plasma position, gas flux and sensibility for each element. Results were expressed as $\mathrm{mg} / \mathrm{l}$ (WHO, 2000 and Savioli et al., 2006).

2- Metal Analysis: Metals concentrations were determined using the ICP [Inductively Coupled Plasma Emission Spectrometer (ICAP 6200)], Central laboratory for chemical analysis, Faculty of Agriculture, Assiut University.

(B) Water Chemical quality properties: Water $\mathrm{pH}$ was immediately measured by using a portable $\mathrm{pH}$ meter (ESD, Engineero Systems and Designs, Model 60 , USA). Electrical conductivity (EC) $(\mathrm{ds} / \mathrm{m})$ and total dissolved solids (TDS) $(\mathrm{mg} / \mathrm{l})$ were measured by EC/TDS/Temperature Bench meter AD3000 (Romania-Europe). Total hardness (TH) mg/l was determined using Lovibond Microprocessor Multidirect photometer, Made in Germany, in Animal Hygiene department, Faculty of veterinary medicine, Assiut University.

[3] Statistical analysis: Data entry and data analysis were done using SPSS version 16 (Statistical Package for Social Science). Data were presented as, mean and standard error. Mann-Whitney test was used to compare quantitative variables between groups. Spearman correlation was done to measure correlation between quantitative variables. P-value considered statistically significant when $\mathrm{P}<0.05$. 

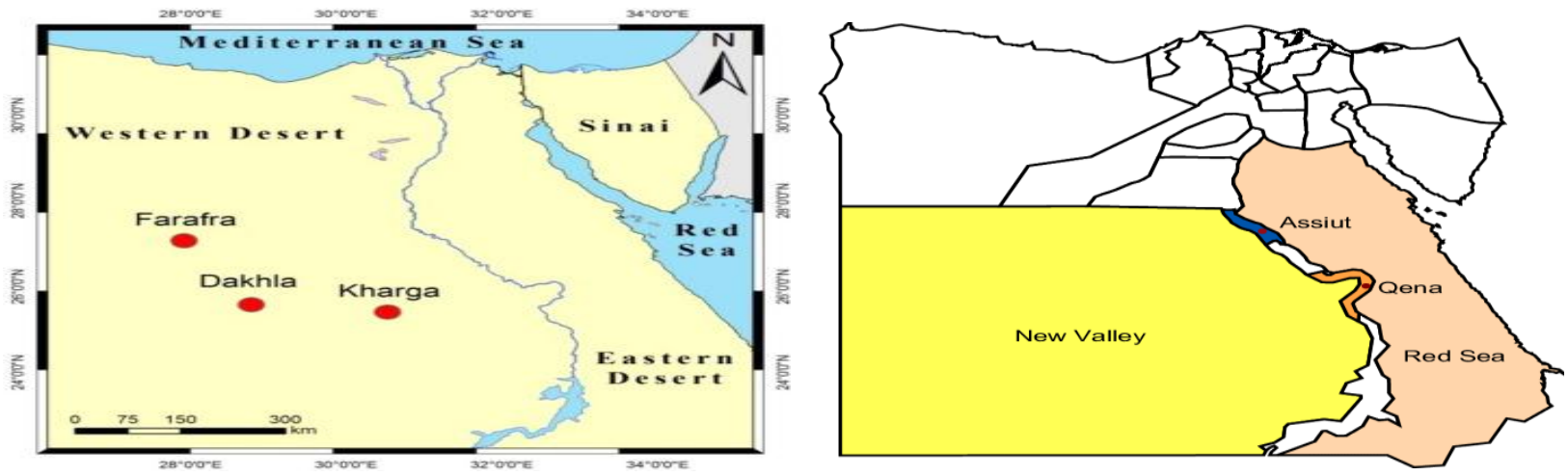

Figure 1: Google Map of Egypt showing the location of the area of study.

\section{RESULTS}

The current results were summarized in tables 1-3. The mean value of Lead $(\mathrm{ppm})$ was $0.803 \pm 0.011$ (0.250-3.033), the highest levels were recorded in water samples of well No.10 while the lowest levels were in wells No. 5 and 6 (table 1). The mean value of $\mathrm{Cd}$ (ppm) was 0.0082 \pm 0.0008 (0.0001-0.0325) where the highest level was detected in water samples of well No. 3 and the lowest level was detected in wells No. 6, 7 and 9. The mean concentration of $\mathrm{Mn}$ (ppm) was 30.595 \pm 0.197 (4.225-56.325), the highest levels were detected in wells No. 3,6, 9 and the lowest levels were detected in wells No. 5 and 8 (table 1). The mean concentration of Iron (ppm) was 326.233 \pm 3.077 (27.75-521.75), the highest levels were detected in wells No. 4, 7and 9 while the lowest levels were detected in wells No. 5 and 8 . The mean value of $\mathrm{Cu}$ (ppm) was $0.375 \pm 0.002(0.150-1.125)$. The highest level was detected in water samples of well No. 10 while the lowest level was detected in well No. 7. The mean value of $\mathrm{Zn}$ (ppm) was 9.256 \pm 0.222 (5.150-14.833), the highest level was in wells No. 4, 7 while the lowest levels were detected in wells No $3,6,8$ and 9 (table 1 ).

Table 1: Heavy metals concentrations (ppm) in different examined wells.

\begin{tabular}{|c|c|c|c|c|c|c|}
\hline \multirow{2}{*}{$\begin{array}{c}\text { Wells No. } \\
\text { (samples/wells) }\end{array}$} & \multicolumn{6}{|c|}{ Heavy metals concentrations $(\mathrm{ppm})($ mean $\pm \mathrm{SE})$} \\
\hline & $\mathbf{P b}$ & $\mathbf{C d}$ & Mn & $\mathbf{F e}$ & $\mathbf{C u}$ & Zn \\
\hline 1 & $\begin{array}{c}0.750 \pm \\
0.029^{c}\end{array}$ & $\begin{array}{c}0.0100 \pm \\
0.0001^{\mathrm{a}}\end{array}$ & $\begin{array}{c}23.500 \pm \\
0.194^{\mathrm{b}}\end{array}$ & $\begin{array}{l}202.666 \\
\pm 0.720^{b}\end{array}$ & $\begin{array}{c}0.325 \pm \\
0.015^{\mathrm{b}}\end{array}$ & $\begin{array}{c}8.925 \pm \\
0.035^{\mathrm{b}}\end{array}$ \\
\hline 2 & $\begin{array}{l}0.500 \pm \\
0.024^{\mathrm{b}}\end{array}$ & $\begin{array}{c}0.0066 \pm \\
0.0008^{\mathrm{b}}\end{array}$ & $\begin{array}{c}25.725 \pm \\
0.135^{\mathrm{b}}\end{array}$ & $\begin{array}{l}264.166 \\
\pm 1.890^{\mathrm{b}}\end{array}$ & $\begin{array}{c}0.500 \pm \\
0.028^{c}\end{array}$ & $\begin{array}{c}9.100 \pm \\
0.353^{\mathrm{b}}\end{array}$ \\
\hline 3 & $\begin{array}{c}0.750 \pm \\
0.053^{\mathrm{c}}\end{array}$ & $\begin{array}{c}0.0325 \pm \\
0.0005^{\mathrm{c}}\end{array}$ & $\begin{array}{c}50.525 \pm \\
0.141^{\mathrm{c}}\end{array}$ & $\begin{array}{l}306.500 \\
\pm 1.296^{\mathrm{d}}\end{array}$ & $\begin{array}{c}0.325 \pm \\
0.017^{\mathrm{b}}\end{array}$ & $\begin{array}{r}6.625 \pm \\
0.076^{\mathrm{a}}\end{array}$ \\
\hline 4 & $\begin{array}{l}0.500 \pm \\
0.006^{\mathrm{b}}\end{array}$ & $\begin{array}{c}0.0033 \pm \\
0.0006^{\mathrm{d}}\end{array}$ & $\begin{array}{c}29.450 \pm \\
0.707^{\mathrm{b}}\end{array}$ & $\begin{array}{l}520.500 \\
\pm 1.885^{\mathrm{c}}\end{array}$ & $\begin{array}{c}0.275 \pm \\
0.005^{\mathrm{b}}\end{array}$ & $\begin{array}{c}14.833 \pm \\
0.076^{\mathrm{d}}\end{array}$ \\
\hline 5 & $\begin{array}{c}0.250 \pm \\
0.013^{\mathrm{a}}\end{array}$ & $\begin{array}{c}0.0175 \pm \\
0.0013^{\mathrm{e}}\end{array}$ & $\begin{array}{l}4.225 \pm \\
0.0350^{\mathrm{a}}\end{array}$ & $\begin{array}{c}27.750 \pm \\
0.660^{\mathrm{a}}\end{array}$ & $\begin{array}{c}0.225 \pm \\
0.003^{\mathrm{b}}\end{array}$ & $\begin{array}{c}10.850 \pm \\
0.035^{\mathrm{c}}\end{array}$ \\
\hline 6 & $\begin{array}{c}0.250 \pm \\
0.005^{\mathrm{a}}\end{array}$ & $\begin{array}{c}0.0001 \pm \\
0.0000^{f}\end{array}$ & $\begin{array}{c}53.375 \pm \\
0.412^{\mathrm{c}}\end{array}$ & $\begin{array}{l}487.500 \\
\pm 2.828^{c}\end{array}$ & $\begin{array}{c}0.250 \pm \\
0.003^{\mathrm{b}}\end{array}$ & $\begin{array}{c}5.375 \pm \\
0.076^{\mathrm{a}}\end{array}$ \\
\hline 7 & $\begin{array}{c}0.500 \pm \\
0.017^{\mathrm{b}}\end{array}$ & $\begin{array}{c}0.0001 \pm \\
0.0000^{f}\end{array}$ & $\begin{array}{c}28.425 \pm \\
0.094^{\mathrm{b}}\end{array}$ & $\begin{array}{l}521.750 \\
\pm 1.060^{c}\end{array}$ & $\begin{array}{c}0.150 \pm \\
0.001^{\mathrm{e}}\end{array}$ & $\begin{array}{c}13.850 \pm \\
0.029^{\mathrm{d}}\end{array}$ \\
\hline 8 & $\begin{array}{c}0.750 \pm \\
0.029^{c}\end{array}$ & $\begin{array}{c}0.0004 \pm \\
0.0001^{\mathrm{g}}\end{array}$ & $\begin{array}{l}8.300 \pm \\
0.0130^{\mathrm{a}}\end{array}$ & $\begin{array}{c}42.250 \pm \\
0.592^{\mathrm{a}}\end{array}$ & $\begin{array}{l}0.300 \pm \\
0.005^{\mathrm{b}}\end{array}$ & $\begin{array}{r}5.150 \pm \\
0.007^{\mathrm{a}}\end{array}$ \\
\hline 9 & $\begin{array}{l}0.791 \pm \\
0.016^{\mathrm{c}}\end{array}$ & $\begin{array}{c}0.0001 \pm \\
0.0000^{\mathrm{f}}\end{array}$ & $\begin{array}{c}56.325 \pm \\
1.202^{\mathrm{c}}\end{array}$ & $\begin{array}{l}511.250 \\
\pm 2.239^{c}\end{array}$ & $\begin{array}{c}0.275 \pm \\
0.010^{\mathrm{b}}\end{array}$ & $\begin{array}{c}5.675 \pm \\
0.041^{\mathrm{a}}\end{array}$ \\
\hline 10 & $\begin{array}{c}3.033 \pm \\
0.069^{\mathrm{d}}\end{array}$ & $\begin{array}{c}0.0075 \pm \\
0.0011^{\mathrm{b}}\end{array}$ & $\begin{array}{c}26.100 \pm \\
0.247^{\mathrm{b}}\end{array}$ & $\begin{array}{l}378.000 \\
\pm 0.471^{\mathrm{e}}\end{array}$ & $\begin{array}{l}1.125 \pm \\
0.076^{\mathrm{d}}\end{array}$ & $\begin{array}{c}12.183 \pm \\
0.034^{\mathrm{c}}\end{array}$ \\
\hline $\begin{array}{c}\text { Overall mean } \\
\text { Total }(n=30)\end{array}$ & $\begin{array}{c}0.803 \pm \\
0.011 \\
\end{array}$ & $\begin{array}{c}0.0082 \pm \\
0.0008\end{array}$ & $\begin{array}{c}30.595 \pm \\
0.197 \\
\end{array}$ & $\begin{array}{l}326.233 \\
\pm 3.077 \\
\end{array}$ & $\begin{array}{c}0.375 \pm \\
0.002 \\
\end{array}$ & $\begin{array}{c}9.256 \pm \\
0.222 \\
\end{array}$ \\
\hline Min-Max & $\begin{array}{c}0.250- \\
3.033 \\
\end{array}$ & $\begin{array}{c}0.0001- \\
0.0325\end{array}$ & $\begin{array}{l}4.225- \\
56.325 \\
\end{array}$ & $\begin{array}{c}27.75- \\
521.750 \\
\end{array}$ & $\begin{array}{c}0.150- \\
1.125 \\
\end{array}$ & $\begin{array}{l}5.150- \\
14.833 \\
\end{array}$ \\
\hline WHO(2011) & 0.01 & 0.003 & 0.4 & 0.3 & 2 & 3 \\
\hline EPA (2009) & 0.015 & 0.005 & 0.05 & 0.3 & 1.3 & 5 \\
\hline EU (2014) & 0.01 & 0.003 & 0.05 & 0.2 & 2 & -- \\
\hline tian Standards (2007) & 0.01 & 0.003 & 0.05 & 0.3 & 2 & 3 \\
\hline
\end{tabular}


In table 2, the results showed that, the mean value of total TDS was $1476.380 \pm 14.711$ ppm (441.62028.8), the highest levels were recorded in well No.10, the lowest values were recorded in wells No.1 and 9. The overall mean value of EC were $2.307 \pm 0.061(0.690-3.170) \mathrm{ds} / \mathrm{m}$, the highest values were recorded in wells No. 4, 7, 10 and the lowest values were found in wells No. 1 and 9.The mean values of $\mathrm{pH}$ was $6.186 \pm 0.082(5.43-6.72)$, the lowest $\mathrm{pH}$ values were recorded in wells No. 2 and 8. The mean value of total hardness was $467.5 \pm 13.352 \mathrm{mg} / \mathrm{l}(275-525) \mathrm{mg} / \mathrm{l}$. All examined wells showed high concentrations of $\mathrm{TH}$ except well number 1 which showed the lowest value.

Table 2: Chemical characteristics of the analyzed groundwater samples.

\begin{tabular}{|c|c|c|c|c|}
\hline $\begin{array}{c}\text { Wells No. } \\
\text { (samples/well) }\end{array}$ & $\begin{array}{c}\text { TDS } \\
(\mathrm{mg} / \mathrm{l})\end{array}$ & $\begin{array}{c}\text { EC } \\
(\mathrm{ds} / \mathrm{m})\end{array}$ & pH & $\begin{array}{c}\text { TH } \\
(\mathrm{mg} / \mathrm{l})\end{array}$ \\
\hline 1 & $486.400 \pm 12.961^{\mathrm{a}}$ & $0.760 \pm 0.051^{\mathrm{a}}$ & $6.710 \pm 0.022^{\mathrm{a}}$ & $275 \pm 7.071^{\mathrm{a}}$ \\
\hline 2 & $1580.800 \pm 15.371^{b}$ & $2.470 \pm 0.022^{\mathrm{b}}$ & $5.430 \pm 0.089^{\mathrm{a}}$ & $475 \pm 5.656^{c}$ \\
\hline 3 & $1881.600 \pm 21.964^{c}$ & $2.940 \pm 0.050^{c}$ & $6.720 \pm 0.079^{a}$ & $500 \pm 9.899^{c}$ \\
\hline 4 & $1920.000 \pm 43.495^{c}$ & $3.000 \pm 0.036^{\mathrm{c}}$ & $6.040 \pm 0.098^{\mathrm{a}}$ & $525 \pm 8.485^{c}$ \\
\hline 5 & $1497.600 \pm 83.061^{b}$ & $2.340 \pm 0.027^{\mathrm{b}}$ & $6.120 \pm 0.018^{\mathrm{a}}$ & $400 \pm 8.013^{b}$ \\
\hline 6 & $1440.000 \pm 98.523^{b}$ & $2.250 \pm 0.046^{\mathrm{b}}$ & $6.220 \pm 0.013^{\mathrm{a}}$ & $500 \pm 10.370^{c}$ \\
\hline 7 & $1945.600 \pm 56.977^{\mathrm{c}}$ & $3.040 \pm 0.093^{\mathrm{c}}$ & $6.000 \pm 0.080^{\mathrm{a}}$ & $500 \pm 14.613^{c}$ \\
\hline 8 & $1542.400 \pm 90.038^{b}$ & $2.410 \pm 0.036^{\mathrm{b}}$ & $5.950 \pm 0.055^{\mathrm{a}}$ & $500 \pm 6.599^{c}$ \\
\hline 9 & $441.600 \pm 19.421^{\mathrm{a}}$ & $0.690 \pm 0.032^{\mathrm{a}}$ & $6.660 \pm 0.007^{\mathrm{a}}$ & $500 \pm 4.242^{c}$ \\
\hline 10 & $2028.800 \pm 50.048^{d}$ & $3.170 \pm 0.007^{\mathrm{c}}$ & $6.010 \pm 0.098^{\mathrm{a}}$ & $500 \pm 5.185^{c}$ \\
\hline $\begin{array}{l}\text { Overall mean } \\
\text { Total }(n=30)\end{array}$ & $1476.380 \pm 14.711$ & $2.307 \pm 0.061$ & $6.186 \pm 0.082$ & $467.5 \pm 13.352$ \\
\hline Min.-Max. & $441.6-2028.8$ & $0.690-3.170$ & $5.430-6.720$ & $275-525$ \\
\hline WHO (2011) & $<1000$ & -- & $6.5-8$ & -- \\
\hline EPA (2009) & 500 & -- & $6.5-8.5$ & -- \\
\hline $\begin{array}{l}\text { Egyptian Standards } \\
(2007)\end{array}$ & 1000 & 1.4 & $6.5-8.5$ & 500 \\
\hline
\end{tabular}

Correlations between different estimated metals and other water chemical parameters:

Significant positive correlations were recorded between $\mathrm{Pb}-\mathrm{Cu}, \mathrm{Fe}-\mathrm{Mn}$. Positive correlations with no significance were also showed between all other estimated metals. Each of EC, $\mathrm{pH}$, and TH recorded non-significant correlations with all estimated metals. Significant positive correlation was recorded between EC and each of TDS and TH (Table 3).

Table 3: Correlations between the estimated heavy metals and water quality chemical parameters.

\begin{tabular}{|c|c|c|c|c|c|c|c|c|c|c|}
\hline & $\mathbf{P b}$ & Cd & Mn & $\mathbf{F e}$ & $\mathbf{C u}$ & Zn & pH & EC & TDS & TH \\
\hline $\mathbf{P b}$ & 1 & & & & & & & & & \\
\hline Cd & 0.004 & 1 & & & & & & & & \\
\hline Mn & 0.051 & 0.027 & 1 & & & & & & & \\
\hline $\mathbf{F e}$ & 0.068 & 0.416 & $0.998 *$ & 1 & & & & & & \\
\hline $\mathrm{Cu}$ & $0.842^{*}$ & 0.071 & 0.085 & 0.005 & 1 & & & & & \\
\hline $\mathbf{Z n}$ & 0.187 & 0.120 & 0.361 & 0.265 & 0.162 & 1 & & & & \\
\hline pH & -0.091 & 0.362 & 0.430 & 0.101 & -0.118 & -0.295 & 1 & & & \\
\hline EC & 0.215 & 0.216 & -0.197 & 0.092 & 0.322 & 0.472 & -0.333 & 1 & & \\
\hline TDS & 0.217 & 0.215 & -0.193 & 0.092 & 0.328 & 0.465 & -0.316 & $0.997 *$ & 1 & \\
\hline TH & 0.125 & -0.214 & 0.347 & 0.481 & 0.063 & 0.022 & -0.380 & $0.502 *$ & 0.487 & 1 \\
\hline
\end{tabular}




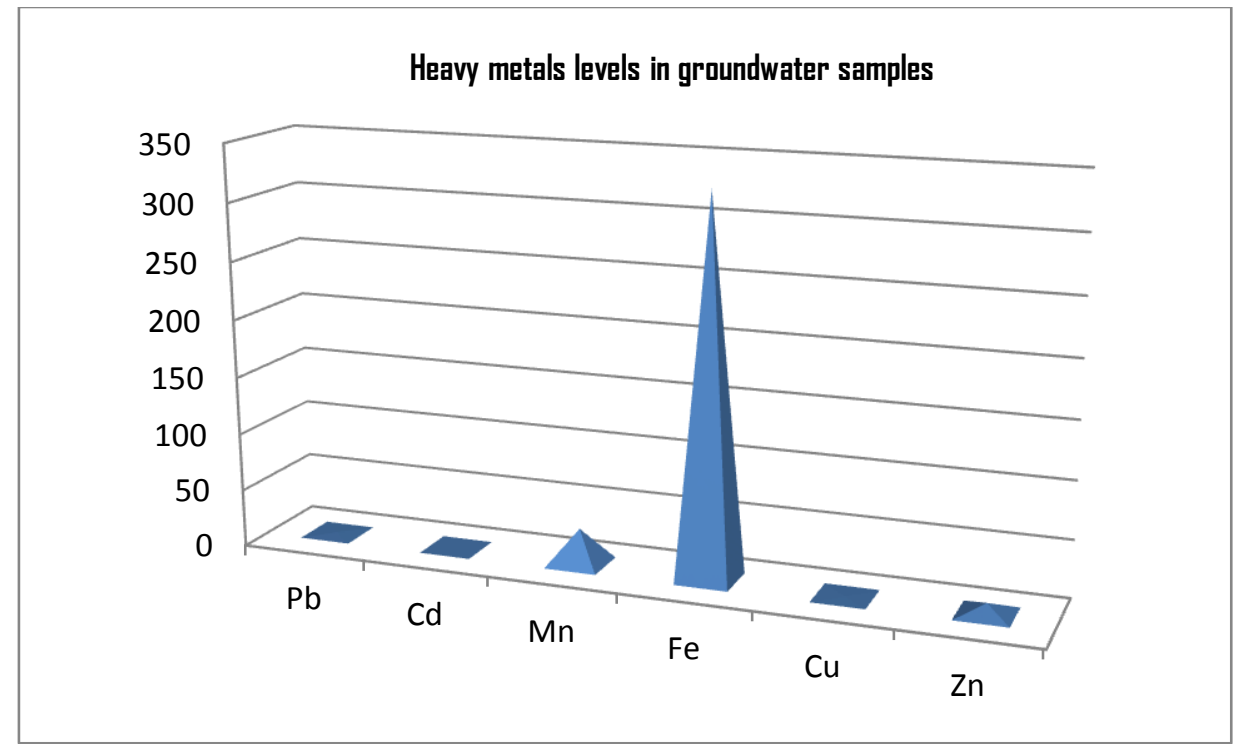

Figure 3: Heavy metals levels in groundwater samples

\section{DISCUSSION}

Lead: Lead concentrations in $100 \%$ of the examined wells, showed higher values than the maximum contamination levels (MCL) listed by WHO (2011), EPA (2009) and Egyptian Standards (2007) (table 1). Lead concentration in well No.10 was significantly higher than other examined wells. Lead in this well may be come from the dissolved lead due to geological precipitation, from surface external contamination, from exhausted fumes or from runoff waste products containing lead or its compounds. The current result of lead values in groundwater samples was higher than that recorded by Hussain et al. (2015) who found that lead level was 0.0-0.007 (ppm) in groundwater samples from Sinai, Egypt and Alshikh (2011) who reported that lead was $<0.0001(\mathrm{ppm})$ in groundwater samples from south Saudi Arabia.

Multiple factors may affect the bioavailability of lead as solubility which is the principal mechanism regulating the concentration of lead in natural waters, $\mathrm{pH}$ value is one of these essential factors (Fergusson, 1990). Recorded $\mathrm{pH}$ values in the current study were acidic or slightly acidic, which may justify the increasing lead values in the examined water samples where if $\mathrm{pH}$ is detained constant, lead solubility diminished with increasing alkalinity (CCREM, 1987), and acidic conditions increases lead solubility (Hem, 1973).

Cadmium: Sixty percent $(60 \%)$ of the examined wells showed $\mathrm{Cd}$ values higher than the MCL of WHO (2011), EPA (2009) and Egyptian Standards (2007). Cadmium level in well No. 1 was significantly higher than other values. The obtained result of cadmium concentration in groundwater was more or less in agreement with Iqbal and Gupta (2009) who recorded mean value of $\mathrm{Cd}$ in ground water samples from India as 0.0075 (ppm) and Mandour (2012) who reported Cd levels fluctuated between 0.001-0.008 (ppm) in groundwater samples collected from different sites at Al- Dakahlyia Governorate in Egypt.

Manganese: Manganese concentrations in all examined wells $(100 \%)$ are higher than MCL listed by WHO (2011), EPA (2009) and Egyptian standards (2007) (table 1). The lowest manganese levels that were recorded in wells number 5 and 8 were significantly different from all other examined wells (Table 1). The current data is somewhat differ from those results were given by each of Al Otaibi and Zaki (2009) who found that only $53.33 \%$ of the collected groundwater samples showed Mn concentrations more than the listed permissible levels. The present evaluated Mn concentrations in groundwater samples was greatly differ from those previously recorded by Alshikh (2011) who found that the mean value of $\mathrm{Mn}$ was $<0.01(\mathrm{ppm})$ in examined groundwater samples from south Saudi Arabia, Mandour (2012) who recorded Mn concentrations ranged from zero to 0.02 in different localities in Dakahlyia Governorate Egypt. The given results agreed to great extend with that obtained by Osman et al. (2012) who reported Mn values up to $65(\mathrm{ppm})$ in ground water samples at Sohag Governorate, Egypt. Our results were greatly differ from that obtained by Hussein et al. (2015) who found that Mn level in examined ground water samples collected from Sinai (Egypt) was ranged between 0.016-0.192 ppm.

Excess of Mn may be present in either ground or surface waters. Mn is capable of causing permanent 
brain damage (James, 1985). Chronic Mn toxicity affecting the CNS causing neurologic disorders. Nephritis, liver cirrhosis, anorexia, muscular fatigue and leukopenia (Mena, 1981). Massive feeding of $\mathrm{Mn}$ to experimental animals retards growth and causes calcium loss and poor absorption of iron which leads to anemia, negative phosphorus balance and rickets (Suzuki, 1975).

Iron: Iron level (ppm) in $100 \%$ of the examined wells were extremely higher than the MCL listed by WHO (2011), EU (2014) and Egyptian Standards (2007). The steep rise in iron levels was strongly evident in all examined wells, as iron levels exceeded the permissible limits hundred times in all examined groundwater samples (table 1). Nevertheless, the relatively low levels of iron that have been recorded in wells No.5 and 8 were significantly different from all other tested wells (Table 1).

These current results were greatly differ from those obtained by Oyeku and Eludoyin (2010) who recorded iron levels ranged between 0.0-21.4 (ppm) in groundwater samples from Nigeria; Mandour (2012) who recorded $\mathrm{Fe}$ values in groundwater samples ranged from $0.006-0.35$ (ppm) in $\mathrm{Al}$ Dakahliya Governorate Egypt; Hussein et al. (2015) who recorded $\mathrm{Fe}$ level 0.00-0.095 (ppm) in groundwater samples collected from Sinai, Egypt and Salem et al. (2014) who recorded Fe levels $(\mathrm{ppm})$ in ground water samples ranged from 0.341.43 at Qena Governorate.

Iron is readily found in water and soil, as rainwater infiltrates the soil layers, iron dissolved and transported into groundwater. Groundwater contains the ferrous form of iron, which can be transported to underground reservoirs and other sources of drinking water. Iron can also reach the drinking water by its using as coatings of many pipes used to transport water, and over time these coatings can begin deteriorating, leading to additional iron reach the water source. Contaminated drinking water with high iron levels is the chief cause of liver cirrhosis (Mandour, 2012).

Copper: The obtained results of this study revealed that all estimated copper values in all examined wells $(100 \%)$ were lower than the limits of EPA (2009), limits listed by WHO (2011), and that of the Egyptian standards (2007) (Table 1). In the same perspective, the significant highest value of copper that recorded in well number 10 was still lower than the listed limits by different organization. this obtained results were somewhat not so far from those values previously estimated in many studies. Iqbal and Gupta (2009) recorded $\mathrm{Cu}$ level as 0.005 $(\mathrm{ppm})$ in groundwater samples from India; Alshikh (2011) found $\mathrm{Cu}$ level< $0.01(\mathrm{ppm})$ in groundwater samples from south Saudi Arabia. Our result for $\mathrm{Cu}$ in groundwater samples was completely differ from that obtained by Mandour (2012) who did not detect $\mathrm{Cu}$ in all investigated groundwater water samples from Al-Dakahlyia Governorate in Egypt.

Copper levels in drinking-water fluctuate widely as a result of dissimilarities in water characteristics such as: $\mathrm{pH}$, hardness and the degree of copper availability in the distribution system (WHO, 2004). Copper is an imperative trace metal that has an essential role in the biochemistry of all living organisms where it directly affects some enzymes activity either as a cofactor or as an ultimate structure of various metalloenzymes. So, cellular respiration, free radical defense, neurotransmitter function and tissue biosynthesis are principally depending on copper levels in an animal body (Scheiber et al., 2014).

Zinc: The obtained values of Zinc concentrations (ppm) in $100 \%$ of the analyzed wells were higher than the MCL listed by both WHO (2011) and Egyptian standards (2007) (table 1). The recorded concentrations in wells No $3,6,8$ and 9 were significantly lower than all other estimated values. However, these concentrations were higher than the MCL listed by both WHO (2011) and Egyptian standers (2007), but slightly around the permissible limits of EPA (2009) (table 1). Estimated Zn values were much higher than those results obtained by Iqbal and Gupta (2009) who recorded $\mathrm{Zn}$ values of $0.851(\mathrm{ppm})$ in groundwater samples from India; Oyeku and Eludoyin (2010) who found $\mathrm{Zn}$ values in groundwater samples from Nigeria were ranged between 0.0-0.23 (ppm); Alshikh (2011) who found that the mean value of $\mathrm{Zn}$ concentration was $<0.005$ (ppm) in examined groundwater samples from south Saudi Arabia and Mandour (2012) found that Zn values were 0.0- $0.07(\mathrm{ppm})$ in groundwater samples from Dakahlyia Governorate - Egypt.

Among all estimated metals in groundwater samples, it is obvious that iron was the highest heavy metal value exceeding all listed permissible limits in a very high rates and was contaminating all examined wells located at different localities. Similarly, each of lead, manganese and zinc values exceeded the listed permissible limits by WHO (2011), EU (2014), EPA (2009) and Egyptian standards (2007). Cadmium, slightly crossed the listed MCL in $60 \%$ of the examined sites (figure 3 ).

In near surface groundwater, pollution is either artificial caused by human activities or natural by salt water intrusions (Skeat, 1969). In addition to its direct harmful impact if drinking water is contaminated with high concentrations of heavy metals as soluble cations, they can pass into the irrigation-drainage network, thus transmitted to both animal and human (Mandour and Azab, 2011). 
For the all obtained results, the sources of these metals may be from the dissolved salts found in water, external surface pollution from air particulate material and finally from the contamination from polluted waste products by these metals.

Total Dissolved Solids: The mean values of TDS in the examined groundwater samples in Eighty percent $(80 \%)$ of the examined wells were higher than the limits of WHO (2011), EPA (2009) and Egyptian standards (2007). The highest recorded concentration in well 10 was significantly different from all examined wells (table 2).

The current obtained results of TDS are higher than those were estimated by Gebrekidan and Samuel (2011) who showed that TDS values were ranged between (44.00-1004.75 $\mathrm{mg} / \mathrm{l})$ in ground water samples collected from Northern Ethiopia. The current results were also higher than those recorded by Salem et al. (2014) who recorded TDS within the acceptable limits in allexamined ground water samples in Qena Governorate. The recorded over all mean value in the current result is lower than that result was obtained by Abdalla et al. (2009) who found that the mean value of TDS in 30 ground water samples at Qena Governorate, Egypt were 1842.93 ppm. Drinking water becomes expressively and progressively unpalatable at TDS Levels higher than $1000 \mathrm{mg} / \mathrm{L}$ (London et al., 2005).

Electric Conductivity: Eighty percentages $(80 \%)$ of the recorded values of EC exceeded the Egyptian standards (2007). Well No.10 showed the significant highest value of EC from all examined wells (table 3 ). The current attained results of the estimated EC values of ten examined wells from Al-Dakhlacity, were lower than those recorded by Hussain et al. (2015) who found that EC was 3.63-15.85 (ds/m) in groundwater samples collected from Sinai.

pH: Seventy percent $(70 \%)$ of the estimated $\mathrm{pH}$ values were slightly around the limits listed by WHO (2011), EPA (2009) and Egyptian standards (2007) (Table 2). No significant difference between any of the estimated $\mathrm{pH}$ values in all examined wells were recorded (Table 2).

The current obtained result was similar to that obtained by Sharkawy (1991) who found that the mean $\mathrm{pH}$ value of groundwater samples collected from Assiut Governorate was 6.79. On the other hand the obtained results were lower than the results were given by each of Gebrekidan and Samuel (2011) who showed that the $\mathrm{pH}$ values of examined water samples from the urban areas of the Tigray region, Northern Ethiopia were ranged between 6.99-8.48; Hussain et al. (2015) who recorded pH values ranged between 7.2-8.8 in groundwater samples from Sinai, Egypt and El-Senousy et al. (2014) who reported that, the mean value of $\mathrm{pH}$ was
7.25 from ground water samples from Sohag Governorate, Egypt.

All recorded $\mathrm{pH}$ values in all examined groundwater samples were within the acidic range, which directly results in increasing the chance of solubility and availability of many heavy metals especially iron since they are negatively correlated, and greatly affect its solubility. This may somewhat explains the extreme values of iron in all examined groundwater samples. Besides the hazardous effect of consuming drinking water with high iron values, utilizing this groundwater of low $\mathrm{pH}$ with high soluble iron in sprinkler irrigation systems cause corrosion for the metallic pipe system (Gameh, 2014).

Total Hardness: This study revealed that, $100 \%$ of the examined wells were above the limits listed by WHO (2007) (200 mg) as a maximum level for total hardness in drinking water while according to Egyptian Standards (2007), $70 \%$ of the examined wells were slightly above the maximum contamination level, while thirty percent of the examined wells were withinor may slightly around these limits (table 2).

Water hardness is the typical measure of water capability to react with soap and hard water imposes substantially more soap to form lather. Hardness mainly originate as a result of natural accumulation of salts from contact with soil and geological formation, due to dissolution of carbonates and sulphates rather than the direct contamination by human activities (Sheikh and Mandre, 2009).

In correlation between the different estimated heavy metals in examined water samples in (Table 3), the current results were more or less in agreement with Laniyan et al. (2011) who analyzed groundwater samples from Lagos (Nigeria) and showed similar results of each of $\mathrm{Pb}-\mathrm{Cu}$ and $\mathrm{Fe}-\mathrm{Mn}$. In relation to the obtained results of water chemical parameter, the given positive correlation with no significance between TDS and both copper and manganese were parallel to that of Shuhaimi-Othman et al. (2009). The obtained significant positive correlation between TDS and EC agreed with that given by Amaal (2005), where the water electrical conductivity greatly depends on the degree its ionic power.

In brief: The variable concentrations in both heavy metals and chemical quality parameters in the analyzed groundwater samples may be as a result of two major factors, firstly: The biogeochemical processes in the soil where the final chemical constituent of groundwater is a direct result of all possible geochemical processes during the percolation of water through the different ground zones (GertKnutsson, 1994). These geochemical reactions such as dissolution and precipitation of 
solids, cations exchange, and adsorption contribute considerably to the variation of groundwaters' elemental concentrations (Elango and Kannan, 2007). Secondly: Groundwater pollution by different types of pollutants may be occur through the circulation of water within the hydrologic cycle where, pollutants occurred on the ground surface have the possibility to be transported through the soil zone towards the aquifer zones where they affect the quality or even damage potable water supplies (Egboka et al., 1998).

\section{CONCLUSION}

- The evaluation of groundwater quality in the New Valley, Al Dakhla Oasis Egypt, revealed that iron, manganese, lead and relatively zinc are the major problems for its use as drinking water, since $100 \%$ of the studied wells were above all limits for drinking water listed by WHO, EPA, EU and Egyptian standers. Hence, handling of this type of contaminated groundwater using appropriate methods of treatment is absolutely necessary before its use for drinking.

- High heavy metals concentrations in most analyzed groundwater samples possess a great hazardous effect if it is used for agricultural purposes, so it must be exposed to certain management and purification before being pumping into the irrigation system.

- Finally to diminish the degradation percent of these important natural water supplies due to contamination processes, a comprehensive management strategy is required where the current control practices with regard to pollution and contamination hazardous effects, predominantly in developing countries, need to be impressively improved.

\section{REFERENCES}

Abbasi, S.A. and Vinithan, S. (1999): "Water quality in and around an industrialized suburb of Pondicherry" Indian J. Environ. Hlth, 41(4): 253-263.

Abdalla, F.A.; Ahmed, A.A. and Omer, A.A. (2009): Degradation of groundwater quality of quaternary aquifer at Qena, Egypt. J of Environmental Studies, 1: 19-32.

Abdul Jameel, A. (2002): Evaluation of drinking water quality in Tiruchirapalli. Ind. J. Environ. Health, 44:108-112.

Adhikari, S.; Ghosh, L. and Ayyappan, S. (2006): Combined effects of water $\mathrm{pH}$ and alkalinity on the accumulation of lead, cadmium and chromium to Labeorohita (Hamilton). Int. J. Environ. Sci. Tech. 3 (3): 289-296.
Al-Otaibi, E.L. and Zaki, M.S.A. (2009): Physicochemical quality of drinking water at Mushait, Aseer, south western Saudi Arabia. Afri J. Clin. and Exper Microbio., 10: 117127.

Alshikh, A.A. (2011): Analysis of Heavy Metals and Organic Pollutants of Ground Water Samples of South Saudi. Life Science Journal, 8(4): 438-441.

Amaal, M. Abdel-Satar (2005): Water quality assessment of River Nile from idfo to Cairo. Egyptian journal of aquatic research 16874285 Vol. 31(2): 200-223.

Anazawa, K.; Kaido, Y.; Shinomura, Y.; Tomiyasu, T. and Sakamoto, H. (2004): Heavy-metal distribution in River waters and sediments around a "Fireflyillage'e, Shikoku, Japan: Application of multivariate analysis. Analytical Sciences, (20): 79-84.

Baptiste, A.R. and Altaff, K. (2002): Water chemistry and heavy metals in some freshwater ponds of Palavakkam, Chennai, Tamil Nadu" Jr. Aqua. Biol., 23-25.

Basavaraddi, S.B.; Kousar, H. and Puttaiah, E.T. (2012): Seasonal variation of groundwater quality and its suitability for drinking in and around Tiptur Town, Tumkur District, Karnataka, India: A WQI Approach. Int. J. Comput. Eng. Res., 2: 562-567.

Bent, S. and Bohm, K. (1995): Copper induced liver cirrhosis in a 13-month-old boy. Gesundheitswesen. V., 57 (10): 667-669.

Bhaskar, C.V.; Kumar, K. and Nagendrappa, G. (2010): Assessment of heavy metals in water samples of certain locations situated around Tumkur, Karnataka, India'. E- Journal of Chemistery 7(2), 349-352.

CCREM (Canadian Council of Resource and Environmental Ministers) (1987): Canadian water quality guidelines. Inland Waters Directorate, Environmental Canada, Ottawa.

Daniela, C. and Scagliarini, M. (2005): Modelling the Effect of Salinity on the Multivariate Distribution of a Water Quality Index Jr. of Math. and Stat., 1(4): 268-272.

Egboka, B.C.E.; Nwankwor, G.I.; Orajaka, I.P. and Ejiofor, A.O. (1989): Principles and problems of environmental pollution of groundwater resources with case examples from developing countries. Environmental Health Prospective, Nigeria.

Egyptian Standard (2007): Ministers Office, Egyptian Standard for Potable Water, Dissection No, (458). Approved at 24/10/ 2007. 3: 424-429.

Ehi-Eromosele, C. and Okiei, W. (2012): Heavy metal assessment of ground, surface and tap water samples in Lagos metropolis using anodic stripping voltammetry. Resour and Environment, 2(3): 82-86. 
Elango, L. and Kannan, R. (2007): " Rock-water interaction and its control on chemical composition of groundwater, In: Sarkar, D., Datta, R., Hannigan, R., (Eds.), Concepts and applications in environmental geochemistry, Elsevier Science, pp. 229-246.

EPA (2005): Toxicological review of zinc and compounds. Washington D.C: U.S. Environmental Protection Agency; 2005.

EPA (2009): Illness related to sewage in water. Accessed 2 April 2009.

EU (European union) (2014): Drinking water regulations statutory instruments. S.I. No. 122.

Ewers, U. and Schlipköter, H-W. (1990): Lead, in Merian, Ernest, ed., Metals and Their Compounds in the Environment: Weinheim, Germany, VCH, p. 971-1014.

Fergusson, J.E. (1990): The Heavy Elements: Chemistry, Environmental Impact and Health Effects. Pergamon Press, Oxford

Fahim, F.A.; Mousa, S.A. and Abdel Aleem, M.K. (1995): Studies on the ground water at an agricultural area, Nile Delta, Egypt Proceedings of the First International Conference on Environment and Development in Africa, 1: 237-255, Assiut University, Assiut, Egypt.

Florence, T.M.; Morrison, G.M. and Stauber, J.L. (1992): Determination of trace element speciation and the role of speciation in aquatic toxicity. Sci. Total Environ. 125: 1-13

FurhanIqbal; NadeemRaza; Mughammad Ali and Mohammad Athar (2005): Contamination of KallarKahar Lake by inorganic elements and heavy metals and their temporal variations. Journal of Applied Sciences \& Environmental Management. Vol. 10 (2): 9598.

Gambrell, R.P.; Wiesepape, J.B.; Patrick, W.H.Jr. and Duff, M.C. (1991): The effects of $\mathrm{pH}$, redox, and salinity on metal release from a contaminated sediment: Water, Air, and Soil Pollution, v. 57-58, p. 359-367.

Gameh, M.A.; Ebtehag, A.S.; El-Habaak, G.H. and Abdel-Moneim, M.M. (2014): Groundwater Potentiality and Suitability for Drinking and Irrigation in the New Valley, Western Desert, Egypt. Assiut J. Agric. Sci., (45) No. (2) (113-124) (7th Conf of Young Scientists), Fac. of Agric. Assiut University April, 28, 2014.

Gazso, L.G. (2001): The key microbial processes in the removal of toxic metals and radionuclide from the environment. CEJOEM 7: 178-185.

Gebrekidan, M. and Samuel, Z. (2011): Concentration of Heavy Metals in Drinking Water from Urban Areas of the Tigray Region, Northern Ethiopia. CNCS, Mekelle University, MEJS, 3(1): 105-121.
Gertknutsson (1994): "Acidification effects on groundwater - prognosis of the risks for the future" Future Groundwater Resources at Risk (Proceedings of the Helsinki Conference), June (1994) Stockholm, Sweden IAHS Publ. no. 222, p 100-144.

Ghulman, B.A.; EL-Bisy, M.S. and Ali, H. (2008): Ground water assessement of makkah almokarama. Proceedings of the $12^{\text {th }}$ International Water Technology Conference, Umm Al-Qura University, Makkah, pp. 1515-1527.

Hefnawy, A. and El-Khaiat, H. (2015): Copper and animal health: Importance, maternal fetal, immunity and DNA relationship, deficiency and toxicity. IJAVMS, Vol. 9, Issue 5, p.195211

Hem, J.D. and Durum, W.H. (1973): Solubility and occurrence of lead in surface water: Am. Water Works Assoc. Jour., v. 65, no. 8, p. $562-568$

Hussein, Kh.A.; Osman, G.A.; El-Gamal, M.S.; Kamel, M.M. and Katry, R.M. (2015): Physico-Chemical and Bacteriological Characteristics of Groundwater of Sinai Desert in Egypt. World Applied Sciences Journal 33 (12): 1929-1939, 2015

Iqbal, M.A. and Gupta, S.G. (2009): Studies on Heavy Metal Ion Pollution of Ground Water Sources as an Effect of Municipal Solid Waste Dumping. African J of Basic \& Applied Sci., 1 (5-6): 117-122

James, R.C. (1985): Neurotoxicity, Toxic effects in the nervous system, In 'Industrial toxicology: P.L. Williams (ed.), Van Nostrand Reinhold Company New York. $1^{\text {Ed }}, 123-137$.

Kastori, R. (1997): Heavy metals in the environment (in Serbian) Feljton. Novi Sad. p. 301.

Laniyan, T.A.; Kehinde Phillips, O.O. and Elesha, L. (2011): Hazards of Heavy Metal Contamination on the Groundwater around a Municipal Dumpsite in Lagos, Southwestern Nigeria. International Journal of Engineering \& Technology IJET-IJENS, 11(5): 53-60.

Laws, E.A. (1981): Aquatic Pollution. Wiley- Interscience Publ. John-Wiley \& Sons. N.Y., USA

London, L.; Dalvie, M.A.; Nowicki, A. and Cairncross, E. (2005): Approaches for regulating water in South Africa for the presence of pesticides. Water SA, 31(1): 5360.

Madsen, H.; Poultsen, L. and Grandjean, P. (1990): Risk of high copper content in drinking water. Ugeskr. Laeger. Jun.18, 152 (25): 1806.

Mamdouh, S.M.; Mohammed, Z. and Adel, M.A. (2003): Study of ground water quality in Kom Hamada area, Beheira Governorate, Egypt. Bulletin of the Chemists and Technologists of Macedonia, 22(2):143-154. 
Mandour, R.A. (2012): Human health impacts of drinking water (surfaceandground) pollution Dakahlyia Governorate, Egypt. Appl Water Sci (2012) 2:157-163.

Mandour, R.A. and Azab, Y.A. (2011): Toxic Levels of Some Heavy Metals in Drinking Groundwater in Dakahlyia Governorate, Egypt in the Year 2010. www.theioem.com 2(2): 112-117.

Mekawi, E.M. (2015): Drinking Water Quality: Chemical Evaluation of Tap Water and Bottled Water In Egypt. Indian J of Applied Res., 5(10): 664-667.

Mena, I. (1981): Manganese. In: Disorders of Mineral Metabolism. Bronner, F., Coburn, J.W. EdsAcdemic Press New York: pp. 233 270.

Mohod, C. and Dhote, J. (2013): Review of heavy metals in drinking water and their effect on human health. International Journal of Innovative Research in Science, Engineering and Technology (IJIRSET), 2 (7): 2992-2996.

Nweke, OC. and Sanders, Iii WH. (2009): Modern environmental health hazards: a public health issue of increasing significance in Africa. Environ Health Perspect 117:863-870.

Orebiyi, E.O.; Awomeso, J.A.; Idowu, O.A.; Martins, O. and Oguntoke \& Taiwo, A.M. (2010): Assessment of pollution hazards of shallow well water in Abeokuta and environs, southwest, Nigeria. American J of Environmental Science, 6(1):50-56.

Osman, G.A.; Shaban, A.M.; Melegy, A.A.; Hassaan, M.M. and Salman, S.A. (2012): A baseline study on microbial and inorganic chemicals contaminants of health importance in ground water and surface water of Sohag Governorate, Egypt. Journal of Applied Sciences Research, 8(12): 5765-5773.

Oyeku, O.T. and Eludoyin, A.O. (2010): Heavy metal contamination of ground water resources in a Nigerian urban settlement. African $\mathbf{J}$ of Environmental Science and Technology, 4(4): 201-214.

Phyllis, K. Weber Scannell and Lawrence, K. Duffy (2007): Effects of Total Dissolved Solids on Aquatic Organisms: A Review of Literature and Recommendation for Salmonid species American J of Environmental Sci., 3 (1):1- 6.

Prasad, P.M.N. and Rami Reddy, Y.V. (2011): TIDEE (TERI Information Digest on Energy and Environment), Volume 10, Number 2.

Prosi, F. (1989): Factors controlling biological availability and toxic effects of lead in aquatic organisms: The Science of the Total Environment, v. 79, p. 157-169.

Rajappa, B.; Manjappa, S. and Puttaiah, E.T. (2010): Monitoring of heavy metal concentration in groundwater of Hakinaka Taluk, India. Contemporary Engineering Sci, 3(4): 183- 190.
Rajkovic, M.B.; Lacnjevac, C.M.; Ralevic, N.R.; Stojanovic, M.D.; Toskovic, D.V.; Pantelic, G.K.; Ristic, N.M. and Jovanic, S. (2008): Identification of metals (heavy and radioactive) in drinking water by indirect analysis method based on scale tests. Sensors, 8: 2188-2207.

Ravindark, K.; Ameena; Meenakshi; Monika; Rani and Kaushik, A. (2003): Seasonal variations in physico-chemical characteristics of River Yamuna Haryana and its ecological bestdesignated use. J. Envirion. Monit. 5(3): 419426.

Salem, W.M.; Sayed, W.F. and Damarany, Kh.A. (2014): Seasonal physic-chemical and microbiological pollutants of potable ground water in Qena Governorate, Egypt: A case study. African $\mathbf{J}$ of Envirovnmental Science and Technology, 8(12): 730-739.

Sampat, P. (2001): The hidden threat of ground water pollution: USA Today, 130.

Sanosi, A.; Samera; Sahar, A.; Abu El-Wafa; M.H. Rateb and Mostafa A. Saleh (2015): Trace element concentrations in ill-thrifted calves in relation to the ecology of El- Kharga Oasis, The New- Valley Province, Egypt. Assiut Vet. J. (16) 144: 145-150

Savioli, L.; Smith, H. and Thompson, A. (2006): Giardia and Crytosporidium join the 'Neglected Disease Iniative'. Trends Parasitol., 22: 203-2-8.

Scheiber, I.F.; Mercer, J.F. and Dringen, R. (2014): Metabolism and functions of copper in the brain. Progress in Neurobiology, 2014. 116, 33-57.

Shaikh, A.M. and Mandre, P.N. (2009): Seasonal study of physic-chemical parameters of drinking water in Khed (Lote) industrial area. Int. Res. J., 2: 169-171.

Sharkawy, A.A. (1991): Lead levels in macro- and microenvironment of cattle at Assiut Governorate. Master Thesis of Veterinary Sciences. Fac. Vet. Medicine, Assiut University, Assiut, Egypt.

Shuhaimi-Othman, M.; Ahmad, A.K. and Lim, E.C. (2009): Metals concentration in water and sediment of Bebar Peat Swampy Forest River, Malaysia. J. Biol. Sci. 9: 730-737.

Skeat, WO. (1969): Water Quality and Treatment. Manual of British Water Engineering Practice. The Institution of Water Engineers. London.

Soltan, M.E. (1998): Characterization, classification and Evaluation of some ground water samples in Upper Egypt. Chemosphere, 37(4): 735-745.

SPSS (2001): "Statistical software package for the social sciences." SPSS Inc. United States of America. Cited by http://www.spss.com.

Stumm, W. and Morgan, J.J. (1996): Aquatic Chemistry, Chemical Equilibria and Rates in 
Natural Waters, 3rd ed. John Wiley \& Sons, Inc., New York, 1022p.

Suzuki, K. (1975): Study on dermal excretion of metallic elements ( $\mathrm{Na}, \mathrm{K}, \mathrm{Ca}, \mathrm{Fe}, \mathrm{Mn}, \mathrm{Cu}$, $\mathrm{Cd}, \mathrm{Pb})$, XthInternat. Cong. Natur. 1520.

Thomas, R.C. and Robert, L.M. (1973): Water and its impurities. $2^{\text {nd }}($ ed.), Dowden, Hutchingon and Ross, Inc. Stroudsburg, Pennsylvania.

Thomson, RM. and Parry, GJ. (2006): Neuropathies associated with excessive exposure to lead. Muscle Nerve, 33: 732-741.

UNESCO (2011): Ground Water Pollution. International Hydrological Programme. 2000. Guidelines for drinking water quality, 4th edition, WHO, 2011.

US EPA (1976): Quality Criteria for Water. Washington, D.C.; US Government Printing Office, 256.

Wang, LK.; Chen, JP.; Hung, YT. and Shammas, NK. (2009): Heavy metals in the environment. London: Taylor and Francis.

WHO (World Health Organization) (1985): Global environmental monitoring system. Guidelines for the study of dietary intakes of chemical contaminants. Geneva, WHO, Offset publication No 87.

WHO (2000): Water supply and sanitation council, global water supply and sanitation assessment 2000 report. New York: UNICEF; 2000.

WHO (2004): Guidelines for Drinking-water Quality: Copper in Drinking-water.

WHO (2006): National water quality guidelines for domestic consumption.

WHO (2007): "Water Quality for Ecosystem and Human Health", 2006 \&"Global Drinking Water Index Development and Sensitivity Analysis Report". WHO (2011): Guideline for drinking water quality. Recommendations. 4 $^{\mathrm{Ed}}$. ISBN. Geneva, World Health Organization.

Zhou, Q.J.; Zhang, J.Fu; Shi, J. and Jiang, G. (2008): Biomonitoring an appealing tool for assessment of metal pollution in the aquatic ecosystem Anal. Chim. Acta. 606: 135-150.

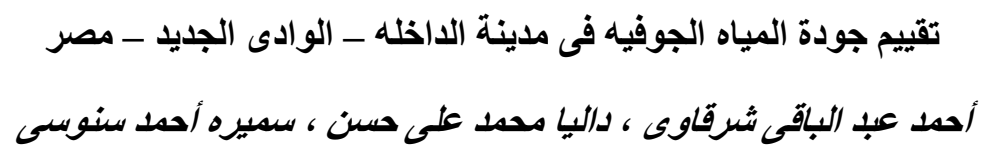

E-mail: ahmedsharkawy61@yahoo.com Assiut University web-site: www.aun.edu.eg

لقد تمت هذه الدر اسه فى منطقة الداخله ــ الو ادى الجديد لبحث جودة المياه الجوفيه المستخدمه فى الثرب. فلقد تم تجميع عدد ثلاثين

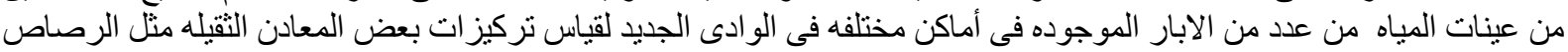

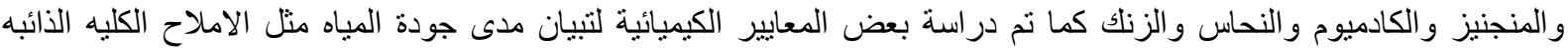

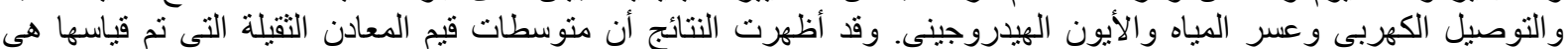

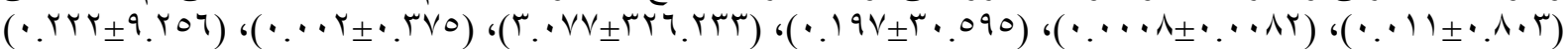

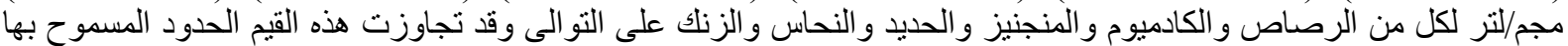

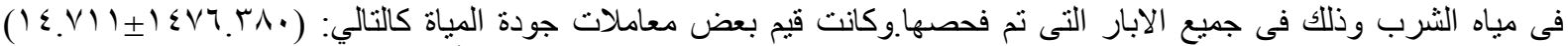

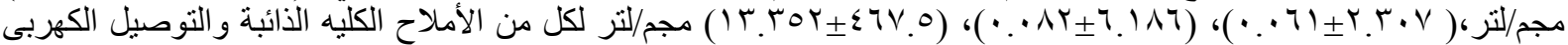

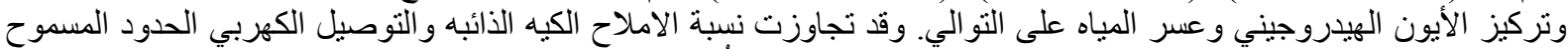

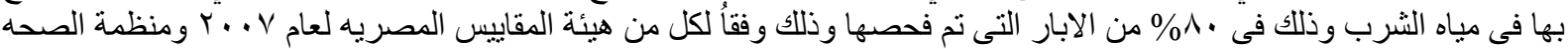

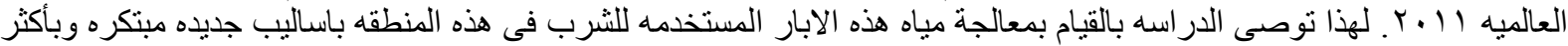

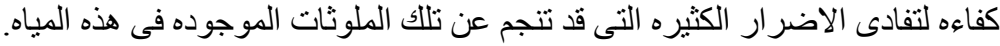

